\title{
Pelaksanaan Standar Pelayanan Kefarmasian di Apotek di Beberapa Kota Indonesia
}

\section{The Implementation of Pharmaceutical Services Standard in Pharmacies in Several Cities in Indonesia}

\author{
Sudibyo Supardi ${ }^{1}$, Yuyun Yuniar ${ }^{1}$, Ida Diana Sari ${ }^{1}$ \\ 1) Pusat Penelitian dan Pengembangan Sumber Daya dan Pelayanan Kesehatan, Jalan Percetakan Negara No. 29 Jakarta \\ 10560, Indonesia \\ Korespondensi: sudibyosupardi@gmail.com
}

Submitted: 25 Oktober 2019, Revised: 23 Desember 2019, Accepted: 30 Desember 2019

https://doi.org/10.22435/jpppk.v3i3.3177

\begin{abstract}
Abstrak
Peraturan Menteri Kesehatan Nomor 73 tahun 2016 tentang Standar Pelayanan Kefarmasian di Apotek antara lain menyatakan bahwa apoteker dalam menjalankan pekerjaan kefarmasian di apotek harus menerapkan standar pelayanan kefarmasian. Penelitian ini bertujuan untuk mengetahui pelaksanaan standar pelayanan kefarmasian di apotek. Desain penelitian yang digunakan adalah potong lintang (cross sectional) dilakukan pada Februari-November 2017. Lokasi penelitian dipilih secara purposif berdasarkan sistem regionalisasi Badan Pengelola Jaminan Sosial (BPJS) bidang kesehatan, yaitu ibukota Provinsi Jawa Barat, Jawa Timur, Sumatera Selatan. Nusa Tenggara Barat, Aceh, Sulawesi Utara, Sulawesi Selatan, Kalimantan Selatan, Kalimantan Tengah, Maluku Utara dan Papua. Sampel meliputi 21 apotek yang bekerjasama dengan BPJS Kesehatan di 11 ibu kota provinsi penelitian. Alat pengumpul data berupa daftar tilik standar pelayanan kefarmasian di apotek. Analisis data dilakukan secara deskriptif. Hasil penelitian menunjukkan bahwa rasio jumlah apoteker per apotek 1,8 dan kecukupan apoteker untuk pelayanan resep pasien per hari tanpa bantuan tenaga teknis kefarmasian sebesar 66,7\%. Standar Pelayanan Kefarmasian di Apotek belum dilaksanakan secara lengkap, rerata pelaksanaan standar pengelolaan sediaan farmasi $(98,4 \%)$ lebih tinggi daripada pelaksanaan standar pelayanan farmasi klinik $(73,8 \%)$. Dalam upaya meningkatkan pelaksanaan SPKA disarankan agar apoteker meningkatkan kompetensi pelayanan kefarmasian di apotek, organisasi profesi melakukan pendidikan berkelanjutan terhadap apoteker dan Dinas Kesehatan Kabupaten/Kota membuat kebijakan, melakukan pembinaan dan monitoring/evaluasi secara berkala.
\end{abstract}

Kata kunci: apotek, farmasi klinik, pengelolaan sediaan farmasi, tenaga kefarmasian

\begin{abstract}
Minister of Health Regulation No. 73 of 2016 on the Pharmaceutical Service Standards in Pharmacy, states that pharmacists should comply and apply the standards. This study aims to identify the implementation of pharmaceutical service standards in pharmacies. The research was cross-sectional and conducted in FebruaryNovember 2017. The selection of research locations was conducted purposively based on the regionalization system of the BPJS Kesehatan. They were 11 capital cities of provinces, namely West Java, East Java, South Sumatra, West Nusa Tenggara, Special regional of Aceh, North Sulawesi, South Sulawesi, South Kalimantan, Central Kalimantan, North Maluku, and Papua. The sample included 21 pharmacies in collaboration with BPJS Kesehatan (Social Security Administrator for Health) in 11 capital cities of the provinces. Data were collected by using a checklist of pharmacy service standards. Data analysis was performed descriptively. The results showed that the ratio of the number of pharmacists per pharmacy was 1.8 and the adequacy of pharmacists for prescription services for patients per day without the help of pharmaceutical technical personnel was $66.7 \%$. Pharmaceutical Service Standards in Pharmacy have not been fully implemented. The
\end{abstract}


average implementation of pharmaceutical preparation management standards $(98.4 \%)$ is higher than the implementation of clinical pharmaceutical service standards (73.8\%). In order to improve the implementation of Pharmaceutical Service Standards, it is recommended that pharmacists increase the competency of services in pharmacies, professional organizations conduct continuing education of pharmacists and the District Health Office should develop policies, conducts training, and periodically strengthen the monitoring and evaluation on the compliance to this standard.

\section{Keywords: pharmacy, clinical pharmacy, pharmaceutical management, pharmaceutical personnel}

\section{Pendahuluan}

Peraturan Pemerintah Nomor 51 Tahun 2009 tentang pekerjaan kefarmasian antara lain menyebutkan bahwa pekerjaan kefarmasian dalam pengadaan, produksi, distribusi dan pelayanan sediaan farmasi harus dilakukan oleh tenaga kesehatan yang mempunyai keahlian dan kewenangan untuk itu. Tenaga yang kompeten dalam pekerjaan kefarmasian adalah tenaga kefarmasian, yang terdiri atas Apoteker dan Tenaga Teknis Kefarmasian (TTK). Dalam menjalankan pekerjaan kefarmasian pada fasilitas pelayanan kefarmasian, apoteker harus menerapkan standar pelayanan kefarmasian. ${ }^{1}$ Pelayanan Kefarmasian adalah suatu pelayanan langsung dan bertanggung jawab seorang apoteker kepada pasien yang berkaitan dengan sediaan farmasi dengan maksud mencapai hasil yang pasti untuk meningkatkan mutu kehidupan pasien. Fasilitas pelayanan kefarmasian adalah sarana yang digunakan untuk menyelenggarakan pelayanan kefarmasian, salah satunya adalah apotek. ${ }^{2}$

Apotek adalah sarana pelayanan kefarmasian tempat dilakukan praktik kefarmasian oleh Apoteker. Apotek harus dikelola oleh seorang apoteker yang profesional, berlokasi di daerah yang mudah dikenali oleh masyarakat dan terdapat papan petunjuk yang tertulis kata “apotek”. Apotek harus mudah diakses oleh masyarakat untuk memperoleh obat termasuk informasi obat dan konseling. Apotek harus memiliki ruang tunggu yang nyaman bagi pasien, tempat untuk mendisplai informasi bagi pasien, termasuk penempatan brosur/materi informasi, ruangan/tempat khusus untuk konseling bagi pasien yang dilengkapi dengan meja dan kursi serta lemari untuk menyimpan catatan medikasi pasien; ruang peracikan obat dan tempat pencucian alat. $^{3}$

Standar Pelayanan Kefarmasian di Apotek (SPKA) meliputi dua kegiatan yaitu yang bersifat manajerial berupa standar pengelolaan sediaan farmasi dan standar pelayanan farmasi klinik. Pengelolaan sediaan farmasi (obat, bahan obat, obat tradisional dan kosmetika) merupakan suatu urutan kegiatan dimulai dari perencanaan kebutuhan, pengadaan, penerimaan, penyimpanan, pemusnahan, dan pencatatan/ pelaporan. Pelayanan farmasi klinik merupakan pelayanan langsung yang diberikan oleh apoteker kepada pasien dalam rangka meningkatkan outcome terapi dan meminimalkan risiko terjadinya efek samping yang meliputi pengkajian dan pelayanan resep, pelayanan informasi obat (PIO), home care, pemantauan terapi obat (PTO), monitoring efek samping obat (MESO), dan konseling termasuk untuk swamedikasi dan pencatatan obat yang digunakan pada PMR (patien medication record). ${ }^{2}$

Pelayanan Kefarmasian di Apotek pertama kali diatur dalam Keputusan Menteri Kesehatan RI nomor 1027/Menkes/SK/IX/2004 tentang SPKA pada tahun 2004. Kemudian diganti dengan Peraturan Menteri Kesehatan (Permenkes) RI nomor 35 Tahun 2014 tentang SPKA dan diperbarui dengan Permenkes RI nomor 73 Tahun 2016 tentang SPKA. Adanya Undang-undang Nomor 23 tahun 2014 tentang Pemerintahan Daerah yang antara lain menyatakan kabupaten/kota sebagai daerah otonom dalam menyelenggarakan urusan pemerintahan yang menjadi kewenangannya wajib berpedoman pada norma, standar, prosedur dan kriteria yang ditetapkan oleh pemerintah pusat, maka pelaksanaan SPKA menjadi tanggung jawab kabupaten/kota. ${ }^{4}$ Tujuan penelitian ini adalah untuk mengetahui sejauh mana pelaksanaan SPKA di kota-kota beberapa provinsi Indonesia.

\section{Metode}

Penelitian ini menggunakan disain potong lintang (cross sectional) dilakukan pada apotek di lima regional di Indonesia sesuai Permenkes RI nomor 27 tahun 2014 tentang Petunjuk Teknis 
Sistem Indonesian Case Based Groups (INACBGs) pada bulan Februari-November 2017. Pemilihan lokasi provinsi dilakukan secara purposif berdasarkan sistem regionalisasi BPJS, yaitu provinsi Jawa Barat, Jawa Timur, Sumatera Selatan. Nusa Tenggara Barat, Aceh, Sulawesi Utara, Sulawesi Selatan, Kalimantan Selatan, Kalimantan Tengah, Maluku Utara dan Papua. Setiap kota sebagai ibu kota provinsi diambil 2 apotek dengan kriteria inklusi apotek yang bekerja sama dengan BPJS dan melayani obat PRB, sehingga diperoleh sampel 22 apotek. Pada saat pengumpulan data ada 1 apotek di Kota Manado dieksklusi karena masih belum melayani pasien BPJS, sehingga penelitian jumlahnya 21 apoteker pengelola apotek.

Alat pengumpul data berupa daftar tilik yang disusun berdasarkan butir-butir kegiatan standar pelayanan kefarmasian di apotek yang mencakup tujuh butir pengelolaan sediaan farmasi dan enam butir pelayanan farmasi klinik. Butir kegiatan pengendalian obat tidak ditanyakan karena isi kegiatannya sudah tercakup dari perencanaan kebutuhan sampai monitoring dan evaluasi, sehingga total butir pengelolaan obat ada enam. Kecukupan tenaga kefarmasian mengacu pada lampiran Permenkes RI nomor 74 tahun 2016 tentang standar pelayanan kefarmasian di Rumah sakit, yaitu rasio seorang apoteker mampu melayani maksimal 50 lembar resep pasien rawat jalan per hari. ${ }^{5}$ Pengisian daftar tilik dilakukan melalui self assessment oleh apoteker pengelola apotek dan penjelasan tambahan bila diperlukan. Analisis data dilakukan secara deskriptif. Penelitian ini merupakan bagian dari Laporan Penelitian Distribusi, Ketersediaan Serta Pelayanan Obat dan Vaksin Dalam Menghadapi Jaminan Kesehatan Semesta 2019, yang mendapatkan persetujuan Komisi Etik Penelitian Kesehatan Badan Litbangkes nomor LB.02.01/2/ KE.102/2017. ${ }^{6}$
Hasil

\section{Kecukupan Jumlah Tenaga Kefarmasian}

Tabel 1 menunjukkan bahwa dari 21 apotek, rerata rasio jumlah apoteker per apotek 1,8 dan jumlah TTK per apotek 4,1. Rerata resep yang diterima apotek per hari 76,8 lembar dan $66,7 \%$ apotek yang memiliki tenaga apoteker mampu melayani resep pasien rawat jalan tanpa bantuan apoteker pendamping atau TTK. Mengingat kriteria apotek sampel adalah apotek yang bekerjasama dengan BPJS dan melayani program rujuk balik (PRB), maka dalam penelitian ini diasumsikan apoteker berada di apotek saat pelayanan dan perhitungan kesesuaian hanya didasarkan pada jumlah apoteker dan jumlah resep harian. ${ }^{5}$

\section{Pelaksanaan SPKA}

Tabel 2 menunjukkan bahwa rerata apotek yang melaksanakan SPKA dalam pengelolaan sediaan farmasi sebesar 98,4\%. Umumnya semua pengelolaan sediaan farmasi sudah dilakukan oleh tenaga kefarmasian sesuai peraturan perundangan, namun demikian pada sebagian kecil apotek, perencanaan dan pengadaan obat masih dilakukan oleh bukan tenaga kefarmasian.

Pelayanan farmasi klinik merupakan kewajiban apoteker sesuai peraturan perundangan, dengan demikian pelayanan yang dilakukan oleh tenaga lain dikategorikan sebagai tidak dilakukan. Tabel 3 menunjukkan bahwa rerata apotek yang melaksanakan pelayanan farmasi klinik oleh apoteker atau apoteker dibantu TTK sebesar $73,8 \%$. Pelayanan farmasi klinik banyak dilakukan dalam pelayanan informasi obat dan monitoring efek samping obat, dan kurang dilakukan pada home care dan pemantauan terapi obat. Pelayanan konseling yang dilakukan apoteker sebagian besar terkait konseling swamedikasi $90,5 \%$ dan yang dicatat menggunakan PMR hanya 52,4\%.

Tabel 1. Kecukupan Tenaga Kefarmasian di 21 Apotek Tahun 2017

\begin{tabular}{lcccc}
\hline Tenaga kefarmasian dan resep & Jumlah & $\begin{array}{c}\text { Rerata } \\
\text { Per apotek }\end{array}$ & Minimal & Maksimal \\
\hline Apoteker & 38 & 1,8 & 1 & 5 \\
Tenaga teknis kefarmasian & 87 & 4,1 & 0 & 10 \\
Lembar resep per hari & 1613 & 76,8 & 15 & 250 \\
Jumlah apotek dengan rasio 1 apoteker melayani $\leq 50$ resep & & $\left.14(66,7 \%)^{*}\right)$ \\
\hline
\end{tabular}

*) dihitung per apotek 


\section{Pembahasan}

\section{Kecukupan Jumlah Tenaga Kefarmasian}

Semua apotek minimal memiliki seorang apoteker sebagai penanggung jawabnya, dan ada persyaratan bahwa apotek yang bekerjasama dengan BPJS memiliki apoteker yang bekerja penuh waktu. Hasil wawancara terhadap 19 APA di Jawa Tengah pada saat Penataran dan Uji Kompetensi Apoteker (PUKA) menunjukkan sekitar 50,0\% konsumen apotek belum pernah bertemu dengan apotekernya, dan hanya $5,3 \%$ apoteker yang memberikan informasi obat kepada konsumennya. Apoteker belum bekerja penuh waktu di apotek mungkin dapat disebabkan oleh beberapa faktor. Pertama, umumnya sebagian besar apoteker bukanlah Pemilik Sarana apotek (PSA), mereka hanya sebagai penanggung jawab, pekerjaan sambilan, sehingga waktu kerja mereka lebih difokuskan untuk pekerjaan pokoknya. Kedua, terjadinya pergeseran fungsi apotek yang orientasinya semakin dominan ke bisnis dibandingkan profesi, sehingga pelayanan obat yang cepat dan harga obat yang murah menjadi prioritas dengan mengabaikan pelayanan farmasi klinik. Ketiga, kurang siapnya bekal pengetahuan dan keterampilan apoteker untuk bekerja di apotek, pemikiran mereka sudah terpola bahwa kerja di apotek terkesan santai dan tidak membutuhkan jam kerja yang banyak atau jadwal kunjungannya tidak tentu. $^{7}$

Penelitian terhadap 21 apotek di Kota Banjarbaru menunjukkan frekuensi kehadiran apoteker selama apotek buka 14,3\%, setiap hari pada jam tertentu 14,3\%, 2-3 kali seminggu 14,3\%, sekali seminggu $28,5 \%$, sekali sebulan 28,5\%; memiliki seorang apoteker pendamping $19,0 \%$ dan tidak memiliki 80,9\%; memiliki seorang TTK 0\%, 2 orang

Tabel 2. Standar Pengelolaan Sediaan Farmasi di 21 Apotek Tahun 2017

\begin{tabular}{llcc}
\hline Standar Pengelolaan Sediaan Farmasi & $\begin{array}{c}\text { Dilakukan oleh bukan tenaga } \\
\text { kefarmasian } \\
\text { (\% apotek) }\end{array}$ & $\begin{array}{c}\text { Dilakukan oleh apoteker dan/ } \\
\text { TTK } \\
\text { (\% apotek) }\end{array}$ \\
\hline 1 & Perencanaan sediaan farmasi & 4,8 & 95,2 \\
2 & Pengadaan sediaan farmasi & 4,8 & 95,2 \\
3 & Penerimaan sediaan farmasi & 0,0 & 100,0 \\
4 & Penyimpanan sediaan farmasi & 0,0 & 100,0 \\
5 & Pemusnahan sediaan farmasi & 0,0 & 100,0 \\
6 & Pencatatan/pelaporan sediaan farmasi & 0,0 & 100,0 \\
& Rerata & $\mathbf{1 , 6}$ & $\mathbf{9 8 , 4}$ \\
\hline
\end{tabular}

Tabel 3. Standar Pelayanan Farmasi Klinik di 21 Apotek Tahun 2017

\begin{tabular}{|c|c|c|c|}
\hline & Standar Pelayanan Farmasi Klinik & $\begin{array}{l}\text { Tidak dilakukan oleh } \\
\text { apoteker } \\
\text { (\% apotek) }\end{array}$ & $\begin{array}{c}\text { Dilakukan oleh apoteker, } \\
\text { dibantu TTK } \\
\text { (\% apotek) }\end{array}$ \\
\hline 1 & Pengkajian dan pelayanan Resep & 23,8 & 76,2 \\
\hline 2 & Pelayanan Informasi Obat (PIO) & 4,8 & 95,2 \\
\hline 3 & Konseling *) & 14,3 & 85,7 \\
\hline 4 & Pelayanan farmasi di rumah (Home care) & 52,4 & 47,6 \\
\hline 5 & Pemantauan Terapi Obat (PTO) & 52,4 & 47,6 \\
\hline \multirow[t]{2}{*}{6} & Monitoring efek samping obat (MESO) & 9,5 & 90,5 \\
\hline & Rerata & 26,2 & 73,8 \\
\hline *) & Pelayanan swamedikasi & 9,5 & 90,5 \\
\hline *) & Pencatatan Patient Medical Record (PMR) & 47,6 & 52,4 \\
\hline
\end{tabular}

*) konseling mencakup pelayanan swamedikasi dan pencatatan pada PMR 
$66,7 \%$, lebih dari 2 orang 33,3\%. ${ }^{8}$ Penelitian apotekapotek di Kota Magelang menunjukkan bahwa $54 \%$ apotek memiliki lebih dari satu apoteker, $80 \%$ apoteker datang setiap hari ke apotek (6 jam/hari), dan $80 \%$ apotek memiliki lebih dari satu TTK. ${ }^{9}$ Variabel kehadiran apoteker berpengaruh signifikan terhadap pelayanan kefarmasian. ${ }^{10}$

\section{Pelaksanaan SPKA}

Pelayanan farmasi klinik sangat penting untuk mencapai pengobatan yang aman dan optimal. Riset di Swedia yang membandingkan kelompok pasien antara yang mendapat pelayanan kefarmasian biasa dan pelayanan kefarmasian standar menunjukkan bahwa pasien yang mendapat pelayanan kefarmasian standar merasa lebih aman dengan pengobatannya, diperhatikan dengan baik oleh apoteker, mendapat informasi yang penting dan merasa lebih siap ketika menemui dokter. Berbagai permasalahan yang dialami saat konseling antara lain kesulitan membuka kemasan obat, kekhawatiran efek samping, interaksi obat dan pengobatan yang tidak tepat. ${ }^{11}$

Apoteker dan TTK mempunyai peran penting dalam mencegah kesalahan peresepan dalam e-resep melalui deteksi eror dan verifikasi maksud penulis resep. Kesalahan dalam resep dideteksi dengan pengecekan ulang, mencetak resep dan menggunakan spidol untuk mewarnai. Bila terjadi masalah maka dilakukan reviu riwayat pengobatan pasien, konsultasi dengan pasien atau tim farmasi lainnya dan menggunakan sumber informasi online. Apoteker dan TTK mengoreksi resep dengan melakukan perkiraan ilmiah atau menghubungi penulis resepnya langsung. ${ }^{12}$

Penelitian terhadap apotek-apotek di Kabupaten Brebes didapatkan rerata pelaksanaan SPKA sebesar $69,10 \%$, dan hasil uji statistik disimpulkan bahwa kehadiran apoteker mempunyai pengaruh terhadap pelayanan kefarmasian. $^{13}$ Penelitian terhadap apotek-apotek di Kota Magelang menunjukkan bahwa $60 \%$ Apoteker pernah mengikuti pelatihan kefarmasian, 53\% apoteker melakukan pemeriksaan resep, $80 \%$ Apoteker dan 20\% TTK melakukan dispensing, 73\% apoteker melakukan Pelayanan Informasi Obat (PIO) dengan lengkap, $60 \%$ apoteker melakukan pencatatan dengan lengkap, dan 100\% apoteker melakukan pelaporan narkotika dan psikotropika secara reguler setiap bulan. ${ }^{9}$

Penelitian di apotek-apotek Kota Yogyakarta menunjukkan rerata pengkajian resep dilakukan oleh apoteker $(77,8 \%)$ dan TTK $(22,2 \%)$, rerata peracikan dan pengemasan obat dilakukan oleh apoteker $(64,9 \%)$ dan TTK $(35,0 \%)$, penyerahan obat yang dilakukan oleh apoteker 67,2\% dan TTK 32,8\%. ${ }^{14}$ Pelaksanaan SPKA dalam pemberian informasi obat yang sering disampaikan adalah cara penggunaan, dosis, nama obat dan indikasi, tetapi efek samping, perhatian, interaksi obat, kontraindikasi dan cara penyimpanan masih jarang diberikan. ${ }^{15}$

Hasil tinjauan sistematik terhadap pelayanan konseling oleh apoteker menunjukkan bahwa tingkat konseling pasien berkisar antara 8-100\%. Pada umumnya konseling diberikan lebih banyak pada pasien dengan resep baru dibandingkan resep berulang. ${ }^{15}$ Salah satu faktor yang mengurangi kemauan apoteker untuk memberikan pelayanan dispensing dan konseling dengan kualitas yang tinggi di China adalah kurangnya mekanisme reimbursement. Kekurangan tenaga apoteker yang berkualitas untuk memenuhi kebutuhan pasien dan kurangnya pelatihan menyebabkan pelayanan farmasi tidak menjadi prioritas dalam pelayanan rutin resep. ${ }^{16}$ Selain itu beban kerja yang berat dapat menghambat peran apoteker dalam PIO. ${ }^{17}$

Survey terhadap apotek-apotek di Kabupaten Brebes menunjukkan rerata pelaksanaan SPKA sebesar 69,1\% (termasuk kategori sedang). ${ }^{11}$ Demikian pula penelitian terhadap apotek-apotek di Kota Ketapang menunjukkan rerata skor penerapan SPKA dalam pengelolaan sediaan farmasi sebesar $94,1 \%$ dan dalam pelayanan farmasi klinik sebesar $26,0 \%$, sehingga disimpulkan seluruh apoteker di apotek belum menerapkan SPKA secara menyeluruh. ${ }^{18}$ Hasil serupa menunjukkan bahwa pelayanan kefarmasian masih berorientasi pada obat dan kurang berorientasi kepada pasien. Pelayanan farmasi klinik yang berorientasi pasien pun belum menjadi alasan konsumen dalam memilih apotek. ${ }^{19}$

Hal ini berbeda dengan hasil penelitian di Kanada yang menunjukkan bahwa dengan memperkenalkan pelayanan kefarmasian di apotek dapat meningkatkan kepuasan pasien sehingga pengelola apotek perlu memperhatikan kegiatankegiatan konsultasi yang melibatkan pasien 
dan dokter. ${ }^{20}$ Hasil ulasan sistematik di Inggris menunjukkan bahwa pelayanan farmasi khususnya yang menggunakan kemampuan farmasi klinis dipandang menguntungkan oleh masyarakat dan perlu diketahui baik oleh pasien maupun dokter. ${ }^{21}$ Pelayanan farmasi yang berorientasi kepada pasien di Eropa mengalami perkembangan pada tahun 2012-2013, terutama di Denmark dan Swiss. Namun perkembangan ini dianggap masih lambat disebabkan berbagai masalah yang menghambat pergeseran dari praktek tradisional di apotek. Hal ini memerlukan dukungan dari organisasi profesional disertai kontrak untuk apotek yang melakukan pelayanan kefarmasian seperti pemberian remunerasi. ${ }^{22}$

Penelitian terhadap 32 apotek di Kabupaten Bantul menunjukkan bahwa SPKA belum dilaksanakan dengan baik, yaitu 56,2\% apotek kategori baik, 40,6\% apotek kategori cukup, dan $3,1 \%$ apotek kategori kurang. Indikator yang diimplementasikan dengan baik adalah indikator faktor pendukung $88,9 \%$, ketenagaan $87,6 \%$, dan pengelolaan sediaan farmasi $82,3 \%$. Indikator lainnya, yaitu komunikasi, informasi, dan edukasi $75,6 \%$, administrasi $68,2 \%$, dan pelayanan sediaan farmasi $64,9 \%$, masuk dalam kategori cukup. ${ }^{23}$

Penelitian terhadap 6 APA, seorang apoteker Kepala Seksi Farmasi Dinkes, seorang apoteker Balai Pengawas Obat, Makanan dan Minuman (POM) dan seorang apoteker Ketua Ikatan Apoteker Indonesia (IAI) di Kabupaten Semarang menunjukkan bahwa pelaksanaan SPKA belum optimal karena pemahaman tentang SPKA belum memadai, SOP/Prosedur tetap belum ada, sosialisasi serta pembinaan/ petunjuk teknis dari Dinas Kesehatan dan IAI Cabang Kabupaten Semarang belum ada. ${ }^{24}$ Penelitian terhadap 70 apotek di Jakarta, Yogyakarta, Surabaya, Medan, Padang, Banjarmasin dan Makassar melalui diskusi kelompok terarah. menunjukkan bahwa meskipun SPKA telah disosialisasikan kepada apoteker, namun dalam pelaksanaannya belum dilakukan secara lengkap. Apoteker masih memerlukan pelatihan, terutama pada farmakoterapi, informasi obat, dan manajemen sediaan farmasi. ${ }^{25}$ Survey terhadap apotek-apotek di Kota Yogyakarta menunjukkan bahwa SPKA belum dilaksanakan secara lengkap. Faktor yang menghambat pelaksanaan SPKA antara lain program pelatihan, seminar atau bentuk lain yang jarang dilakukan sehingga peluang apoteker untuk mengembangkan diri sangat terbatas. Kemudian kurangnya kegiatan dinas kesehatan setempat dalam sosialisasi dan monitoring/evaluasi secara berkala. ${ }^{26}$

\section{Kesimpulan}

Berdasarkan hasil dan pembahasan, disimpulkan bahwa rasio jumlah apoteker per apotek 1,8 dan kecukupan apoteker untuk pelayanan resep pasien per hari tanpa bantuan tenaga teknis kefarmasian sebesar $66,7 \%$. Pelaksanaan SPKA belum dilakukan secara lengkap, rerata pelaksanaan standar pengelolaan sediaan farmasi $(98,4 \%)$ lebih tinggi daripada pelaksanaan standar pelayanan farmasi klinik (73,8\%).

\section{Saran}

Dalam upaya meningkatkan pelaksanaan SPKA disarankan agar apoteker meningkatkan kompetensi (pengetahuan, keterampilan dan sikap) dalam pelayanan kefarmasian di apotek, organisasi profesi melakukan pendidikan berkelanjutan terhadap apoteker melalui pelatihan/kursus/ seminar untuk pengembangan kompetensi apoteker, dan Dinas Kesehatan Kabupaten/Kota membuat kebijakan, melakukan pembinaan dan monitoring/ evaluasi tehadap pelaksanaan SPKA secara berkala.

\section{Ucapan Terima Kasih}

Terima kasih penulis sampaikan kepada Kepala Puslitbang Sumber Daya dan Pelayanan Kesehatan Badan Litbangkes yang memfasilitasi penelitian ini dan teman-teman peneliti yang membantu pengumpulan data penelitian.

\section{Daftar Rujukan}

1. Peraturan Pemerintah Nomor 51 Tahun 2009 tentang Pekerjaan Kefarmasian.

2. Kementerian Kesehatan RI. Peraturan Menteri Kesehatan Republik Indonesia Nomor 73 Tahun 2016 tentang Standar Pelayanan Kefarmasian di Apotek.

3. Kementerian Kesehatan RI. Peraturan Menteri Kesehatan Republik Indonesia Nomor 9 Tahun 2017 tentang Apotek.

4. Undang-undang Republik Indonesia Nomor 23 Tahun 2014 tentang Pemerintahan Daerah.

5. Kementerian Kesehatan RI. Peraturan Menteri 
Kesehatan Republik Indonesia Nomor 75 Tahun 2016 tentang Standar Pelayanan Kefarmasian di Rumah Sakit.

6. Yuniar Y., Dianasari I., Supardi S., Susyanti AL., Handayani RS., Raharni, dkk. Laporan Hasil Penelitian Distribusi, Ketersediaan Serta Pelayanan Obat dan Vaksin Dalam Menghadapi Jaminan Kesehatan Semesta 2017. Jakarta: Pusat Penelitian dan Pengembangan Sumber Daya Dan Pelayanan Kesehatan, Badan Penelitian dan Pengembangan Kesehatan Kemkes RI. 2017.

7. Dilema Apoteker dalam Pelayanan Kefarmasian [Internet]. Tersedia Pada : http://apotek. dagdigdug.com/ 2008/ 08/Published Agustus 7th, 2008. Tak Berkategori.

8. Kartinah N., Annisa S., Yuniarti T., Setyanto H. Gambaran Pelayanan Kefarmasian di Apotek Wilayah Kota Banjarbaru Berdasarkan Standar Pelayanan Kefarmasian. Prosiding Seminar Nasional \& Workshop "Perkembangan Terkini Sains Farmasi \& Klinik 5." Padang: 6-7 November 2015.

9. Latifah E., Pribadi P., Yuliastuti F. Penerapan Standar Pelayanan Kefarmasian di Apotek Kota Magelang. Jurnal Farmasi Sains dan Praktis, 2016, II(1): 11-17.

10. Dominica D., Putra DP., Yulihasri Y. Pengaruh Kehadiran Apoteker Terhadap Pelayanan Kefarmasian di Apotek di Kota Padang. Jurnal Sains Farmasi \& Klinis, 2016; 3(1): 99-107.

11. Montgomery, AT., Sporrong KS., Manap, N., Tully, MP., Lindblad, ÅK. Receiving a Pharmaceutical Care Service Compared to Receiving Standard Pharmacy Service in Sweden-How Do Patients Differ With Regard to Perceptions of Medicine Use and The Pharmacy Encounter? Research in Social and Administrative Pharmacy. 2010;6(3): 185-95.

12. Odukoya, OK., Stone, JA., Chui, MA. How do community pharmacies recover from e-prescription errors? Research in Social and Administrative Pharmacy. 2014, 83(6): 427437.

13. Wijiyanti, Muhtar A. Gambaran Pelaksanaan Standar Pelayanan Kefarmasian di Apotek Kabupaten Brebes Tahun 2008 [Skripsi]. Surakarta, Fakultas Farmasi Universitas Muhammadiyah, 2009.
14. Sari CP., Mafruhah OR., Fajria RN., Meta A. Evaluasi Pelayanan Resep Berdasarkan Pelaksanaan Standar Kefarmasian di Apotek Tempat Praktik Kerja Profesi Apoteker (PKPA) Kota Yogyakarta Jurnal Pharmascience, 2019; 06 (01): $18-29$.

15. Puspitasari, HP., Aslani P., Krass I. A Review of Counseling Practices on Prescription Medicines in Community Pharmacies. Research in Social and Administrative Pharmacy. 2009; 5(3): 197210.

16. Fang Y., Yang S., Zhou S., Jiang M., Liu J. Community Pharmacy Practice in China: Past, Present and Future. International Journal of Clinical Pharmacy. 2013;35(4): 520-8.

17. Latif A., Pollock K., Boardman H.F. The Contribution of the Medicines Use Review (MUR) Consultation to Counseling Practice in Community Pharmacies. Patient Education and Counseling. 2011; 83 (3): 336-44.

18. Anditasari W., Untari EK., Nansy E. Penilaian Terhadap Penerapan Standar Pelayanan Kefarmasian di Apotek-Apotek di Kota Ketapang Tahun 2016 [Skripsi]. Pontianak, Program Studi Farmasi, Fakultas Kedokteran Universitas Tanjungpura; 2016.

19. Sasanti Handayani R., Raharni, Gitawati R. Persepsi Konsumen Apotek Terhadap Pelayanan Apotek di Tiga Kota di Indonesia. Makara Kesehatan. 2009; 13(1): 22-6.

20. Kassam, R., Collins JB., Berkowitz J. Patient Satisfaction with Pharmaceutical Care Delivery in Community Pharmacies. Patient Preference and Adherence. 2012; 6, 337-48.

21. Hindi AMK., Schafheutle EI., Jacobs S. Patient and Public Perspectives of Community Pharmacies in The United Kingdom: A Systematic Review. Health Expectations. 2018; 21(2): 409-428.

22. Costa, FA., Scullin C., Al-Taani G., Hawwa AF., Anderson C., Bezverhni Z., et al. Provision of Pharmaceutical Care by Community Pharmacists A cross Europe: Is It Developing and Spreading ? Journal of Evaluation in Clinical Practice. 2017; 23(6): 1336-1347.

23. Fauziyah P.N., Satibi. Evaluasi Implementasi Standar Pelayanan Kefarmasian oleh Apoteker di Apotek Kabupaten Bantul. Jurnal Manajemen 
dan Pelayanan Farmasi. 2012; 2(4): 209-213.

24. Cahyono LT., Sudiro., Suparwati A. Pelaksanaan Standar Pelayanan Kefarmasian di Apotek di Kabupaten Semarang. Jurnal Manajemen Kesehatan Indonesia. 2015; 03(02): 100-107.

25. Supardi S., Handayani RS., Raharni, Herman MJ., Susyanty AL. Pelaksanaan Standar
Pelayanan Kefarmasian di Apotek dan Kebutuhan Pelatihan Bagi Apotekernya. Bul. Penelitian Kesehatan. 2011; 39(3): 138-144.

26. Atmini KD., Gandjar IG., Purnomo A. Analisis Aplikasi Standar Pelayanan Kefarmasian di Apotek Kota Yogyakarta. Jurnal Manajemen dan Pelayanan Farmasi. 2011; 1(1): 49-55. 